\title{
PEMBINAAN KELOMPOK USAHA BERSAMA DESA NYOGAN MENUJU DESA SEJAHTERA MANDIRI
}

\author{
${ }^{1}$ Ardiyaningsih Puji Lestari, ${ }^{2}$ Ade Octavia, ${ }^{3}$ Ardi Novra dan ${ }^{4}$ Agus Syarif \\ ${ }^{1}$ Dosen Fakultas Pertanian Universitas Jambi \\ ${ }^{2,4}$ Dosen Fakultas Ekonomi dan Bisnis Universitas Jambi \\ ${ }^{3}$ Dosen Fakultas Peternakan Universitas Jambi
}

Email: naning_unja@yahoo.co.id; octaviafeunja@yahoo.com; ardnov@yahoo.com; agssyarif@gmail.com

\begin{abstract}
ABSTRAK
Di Desa Nyogan terdapat 24 kelompok usaha bersama (KUBE) yang mengelola 12 jenis usaha. Dalam menjalankan usahanya terdapat beberapa masalah yang muncul. Faktor penyebab masalah tersebut antara lain (1) Pemilihan jenis kegiatan usaha kelompok usaha bersama yang kurang tepat dengan kebutuhan masyarakat desa (2) Keterbatasan kemampuan anggota dalam menguasai pengetahuan yang berkaitan dalam menjalankan usaha (3) Keterbatasan atau bahkan tidak adanya kegiatan pengawalan atau pendampingan, dan (4) Kemampuan manajerial yang rendah. Solusi permasalahan yang dapat dilakukan adalah melalui penguatan sumber daya masyarakat dan penguatan usaha keswadayaan masyarakat. Kegiatan yang dilakukan yaitu (1) Pendidikan dan Latihan (Diklat) untuk peningkatan sumber daya manusia sehingga menghasilkan individu yang kreatif inovatif, (2) Melakukan visit study ke pelaku usaha yang dinilai sukses sehingga diharapkan mampu meningkatkan motivasi dan perluasan wawasan anggota KUBE, dan (3) Melakukan pendampingan untuk dapat membantu mengatasi permasalahan permasalahan yang muncul sehingga keberlanjutan usaha dapat lebih terjamin. Hasil yang didapat dari kegiatan ini (1) Peserta merasakan manfaat yang besar dari pelaksanaan kegiatan pengabdian ini, (2) KUBE yang putus asa dan akan menutup usahanya mulai terlihat bersemangat dan berencana untuk mengaktifkan kembali usaha kelompok bersamanya, (3) Peserta KUBE berkolaborasi antar kelompok usaha bersama untuk menerima pesanan paket dari konsumen, (4) Peserta mulai memahami bahwa dalam melakukan usaha tidak selalu langsung menjadi sukses melainkan dapat mengalami hambatan yang berasal dari dalam kelompok maupun luar kelompok dan (5) Adanya keinginan bersama masyarakat dan desa untuk menggali potensi desa untuk dijadikan desa wisata yang dapat menarik wisatawan sehingga dapat membantu meningkatkan kesejahteraan masyarakat.
\end{abstract}

Kata Kunci : Wirausaha, KUBE, Pendampingan Usaha.

\section{PENDAHULUAN}

Desa Nyogan merupakan salah satu desa yang terletak di Kecamatan Mestong Kabupaten Muaro Jambi, dengan jarak dari pusat ibukota provinsi sekitar $35 \mathrm{~km}$ dan $42 \mathrm{~km}$ bila dihitung dari kampus Pinang Masak Universitas Jambi. Luas Wilayah Desa Nyogan adalah $7.872 \mathrm{~km}^{2}$, dalam wilayah ini terdapat 17 Rukun Tetangga (RT) yang berada dalam 4 Dusun, yaitu Dusun Nyogan, Dusun Jerat Harimau, Dusun Nebang Para dan Dusun Selapik. Penduduk yang mendiami kawasan ini berjumlah 3400 jiwa terdiri dari 1.637 Perempuan dan 1763 laki-laki yang berasal dari 970 kepala keluarga. Desa Nyogan memiliki perbedaan bila dibanding dengan desa lainnya yang berada di Muaro Jambi, yaitu bahwa penduduk Desa Nyogan tidak 
hanya berasal dari penduduk asli dan penduduk pendatang saja, melainkan juga terdapat penduduk yang berasal dari suku anak dalam (SAD). Masyarakat Desa Nyogan memiliki mata pencarian yang beragam. Tanaman perkebunan yang ada di lokasi ini didominasi oleh karet dan kelapa sawit. Untuk meningkatkan pendapatan masyarakat, telah dibentuk kegiatan kegiatan usaha yang dikelola secara berkelompok pada masing masing dusun di Desa Nyogan. Namun dengan berjalannya waktu, ternyata sebagian besar usaha yang telah dibentuk tidak mengalami kemajuan dan bahkan cenderung tidak aktif sehingga upaya peningkatan pendapatan melalui kelompok usaha bersama tidak terwujud. Pendapatan per kapita Desa Nyogan masih cukup rendah, sehingga dapat dikatakan dalam kategori desa miskin. Pemerintah menargetkan kemiskinan mengalami penurunan hingga menjadi 7-8\% diakhir RPJMN 2019. Oleh sebab itu, diperlukan sejumlah upaya stratejik yang mampu mempercepat penurunan angka kemiskinan sesuai kewenangan Kementerian Sosial RI berdasarkan UU No.11 Tahun 2009 tentang Kesejahteraan Sosial dan UU No.13 Tahun 2011 tentang Penanganan Fakir Miskin. Salah satu upaya yang perlu dilakukan adalah mengsinergikan berbagai potensi dan sumber kesejahteraan sosial kedalam perlibatan penyelengggaraan kesejahteraan sosial secara komprehenshif. Bahwa untuk mewujudkan keterpaduan penyelenggaraan kesejahteraan sosial dan percepatan penanganan kemiskinan di desa, Kementerian Sosial dan perguruan tinggi, kementerian/lembaga terkait, Pemerintah Daerah dan lembaga sosial lainnya merintis pengembangan Desa Sejahtera Mandiri. Desa Sejahtera Mandiri adalah salah satu model pendekatan kewilayahan untuk kesejahteraan sosial yang dilandasi oleh sinergitas, komprehenshif, integratif dan holistik dalam rangka untuk mewujudkan desa sejahtera dan mandiri. Terdapat beberapa desa di Indonesia yang akan dipersiapkan untuk menjadi Desa Sejahtera Mandiri dan salah satunya terdapat di Propinsi Jambi, yaitu Desa Nyogan Kecamatan Mestong Kabupaten Muara Jambi.

Dalam upaya peningkatan kesejahteraan masyarakat desa, masyarakat Desa Nyogan juga telah berusaha melakukan berbagai kegiatan yang melibatkan berbagai lapisan masyarakat yang menyebar di seluruh wilayah Desa Nyogan. Adapun usaha yang telah dilakukan diantaranya adalah dengan membentuk kelompok usaha kecil secara bersama. Kelompok Usaha Bersama (KUBE) yang telah dibentuk pada tahun 2015 di Desa Nyogan berjumlah 24 kelompok yang terdiri dari 12 jenis usaha. Berdasarkan Undang-Undang Republik Indonesia No. 20 Tahun 2008, yang dimaksud dengan usaha kecil adalah usaha produktif milik orang perorangan dan/atau badan usaha perorangan yang memenuhi kriteria Usaha Mikro sebagaimana diatur dalam Undang-Undang ini. Usaha Kecil adalah usaha ekonomi produktif yang berdiri sendiri, yang dilakukan oleh orang perorangan atau badan usaha yang bukan merupakan anak perusahaan atau bukan cabang perusahaan yang dimiliki, dikuasai, atau menjadi bagian baik langsung maupun tidak langsung dari usaha menengah atau usaha besar yang memenuhi kriteria Usaha Kecil sebagaimana dimaksud dalam Undang-Undang ini. Usaha Menengah adalah usaha ekonomi produktif yang berdiri sendiri, yang dilakukan oleh orang perseorangan atau badan usaha yang bukan merupakan anak perusahaan atau cabang perusahaan yang dimiliki, dikuasai, atau menjadi bagian baik langsung maupun tidak langsung dengan Usaha Kecil atau usaha besar dengan jumlah kekayaan bersih atau hasil penjualan tahunan sebagaimana diatur dalam Undang-Undang ini. 
Di awal pendiriannya, kelompok usaha bersama ini berjalan dengan baik, semua anggota memiliki semangat yang tinggi dalam menjalankan usahanya. Aktivitas kegiatan pada masingmasing kelompok usaha bersama cukup baik dengan kegiatan ekonomi yang cukup aktif. Seiring dengan berjalannya waktu ternyata terjadi perubahan. Kegiatan ekonomi yang semula lancar mulai terasa tersendat-sendat, Satu persatu anggota mulai memperlihatkan penurunan semangat, hingga akhirnya kelompok usaha bersama menjadi kurang aktif.

Dari hasil pertemuan dengan mitra didapatkan informasi bahwa turunnya aktivitas kelompok usaha bersama yang ada di Desa Nyogan dapat disebabkan oleh beberapa hal sebagai berikut (1) Pemilihan jenis kegiatan usaha kelompok usaha bersama yang kurang tepat dengan kebutuhan masyarakat desa akan mengakibatkan rendahnya perputaran ekonomi dalam kegiatan tersebut, dan hal ini dapat mempengaruhi berjalannya dan keberlanjutan usaha. (2) Kemampuan anggota dalam menguasai pengetahuan yang berkaitan dalam menjalankan usaha akan memberikan pengaruh yang nyata terhadap pengembangan usaha. (3) Keterbatasan atau bahkan tidak adanya kegiatan pengawalan atau pendampingan akan memberikan potensi yang besar dalam melahirkan masalah. Masalah - masalah kecil yang tidak mendapatkan solusi pemecahannya akan terakumulasi dan menghasilkan masalah yang besar, dan selanjutnya akan mengancam keberlanjutan usaha. (4) Kemampuan manajerial yang rendah dapat menjadikan kendala dalam menjalankan roda usaha, dan bahkan dapat mematikan usaha.

Transformasi semangat kewirausahaan sebagai pemasukan virus mental ke dalam setiap anggota masyarakat di pedesaan melalui berbagai cara, yang dikemukakan Wasistiono, (2003) yakni melalui penyuluhan/ sosialisasi; melalui pemberian contoh nyata; melalui pemberian kesempatan berusaha; dan melalui proses pembelajaran secara terus-menerus melalui program pendampingan

\section{METODE PELAKSANAAN}

\section{Tempat dan Waktu Pelaksanaan}

Kegiatan ini dilaksanakan di 2 (dua) tempat, yaitu Desa Nyogan Kecamatan Mestong Kabupaten Muaro Jambi dan lokasi tempat pelaku usaha yang dinilai mempunyai kemampuan inovasi yang sangat tinggi. Waktu yang dibutuhkan untuk menyelesaikan kegiatan ini adalah selama 6 bulan.

\section{Metode}

Pelaksanaan kegiatan ini dilakukan dengan menerapkan 3 kegiatan, yaitu (1) Pendidikan dan Latihan (Diklat) untuk peningkatan sumber daya manusia sehingga menghasilkan individu yang kreatif inovatif, (2) Melakukan visit study ke pelaku usaha yang dinilai sukses sehingga diharapkan mampu meningkatkan motivasi dan perluasan wawasan anggota KUBE, dan (3) Melakukan pendampingan untuk dapat membantu mengatasi permasalahan permasalahan kecil yang muncul sehingga keberlanjutan usaha dapat lebih terjamin.

Kesiapan mental mitra mempunyai peranan yang sangat penting dalam menjamin keberlangsungan dan keberlanjutan kegiatan ini. Semangat yang tinggi untuk dapat hidup lebih baik secara lahir dan bathin merupakan modal dasar untuk dapat berkembang menjadi lebih sukses. Untuk dapat menjadi sukses tidak cukup hanya dengan memiliki keinginan saja, 
melainkan juga harus disertai dengan usaha dan semangat pantang menyerah. Pelaksanaan pendidikan dan latihan dilakukan di Desa Nyogan, peserta dalam kegiatan ini adalah warga desa yang tergabung sebagai anggota kelompok usaha bersama, karang taruna dan aparat desa. Dengan demikian peranan Pemerintah Desa dan Warga Desa sangatlah besar dalam mensukseskan kegiatan ini. Tanpa peran serta secara aktif pemerintah desa dan warga masyarakat maka kegiatan ini sulit untuk dilaksanakan.

Peran pemerintah desa adalah dalam hal membantu penyediaan lokasi diklat yang meliputi sebuah bangunan beserta meja kursi dan fasilitas kegiatan lainnya. Selain di dalam ruangan, pelaksanaan kegiatan ini juga dapat dilakukan secara "out door". Adanya perubahan suasana diklat diharapkan dapat meningkatkan kenyamanan dan menghindari kebosanan selama mengikuti kegiatan.

\section{HASIL DAN PEMBAHASAN}

\section{Hasil Pelaksanaan Kegiatan}

Kegiatan pengabdian diawali dengan melakukan peninjauan ke lokasi pelaksanaan kegiatan yang diawali dengan melakukan kunjungan ke Kepala Desa Nyogan Kecamatan Mestong. Dari hasil kunjungan ini ternyata kepala desa menyambut baik rencana kegiatan pengabdian ini dan akan berusaha membantu sepenuhnya pelaksanaan kegiatan pengabdian ini supaya dapat berjalan lancar dan mencapai tujuan.

Selanjutnya dilakukan sosialisasi kepada perangkat desa, pendamping dan anggota kelompok usaha bersama serta karang taruna. Dalam kegiatan ini Tim Pengabdian menyampaikan rencana kegiatan pengabdian yang akan dilaksanakan dan sangat berharap dapat didukung oleh peserta yang hadir. Keberhasilan kegiatan ini tidak hanya tergantung pada tim pengabdian saja, melainkan juga ditentukan oleh peran perangkat desa, pendamping dan anggota kelompok usaha bersama, karang taruna serta semua masyarakat. Alhamdulillah semua peserta yang hadir dalam kegiatan sosialisasi ini tidak ada yang menentang dan keberatan terhadap rencana pelaksanaan kegiatan.

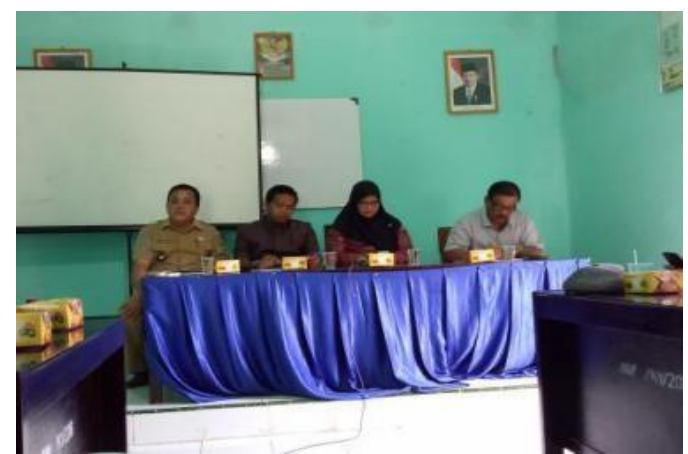

Gambar 1. Sosialisasi oleh Tim

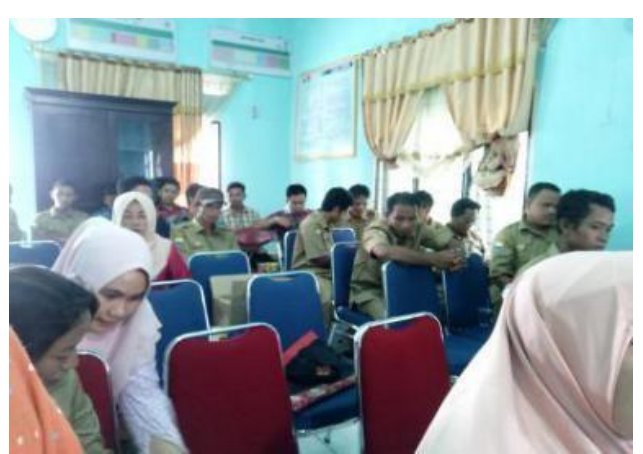

Gambar 2. Peserta Sosialisasi

Kegiatan berikutnya adalah melakukan kesepakatan hari pelaksanaan kegiatan. Dalam menentukan waktu pelaksanaan kegiatan dibutuhkan waktu yang cukup lama, karena harus memadukan waktu kosong dari peserta yang jumlahnya cukup banyak dengan jadwal tim pengabdian yang juga harus melaksanakan kegiatan Tri Dharma Perguruan Tinggi lainnya 
yaitu mengajar dan melaksanakan penelitian. Akhirnya didapatlah kesepakatan bahwa kegiatan tahap I dilakukan pada akhir minggu, yaitu pada Hari Jum'at dan Sabtu, dengan tempat pelaksanaan kegiatan di kantor Kepala Desa Nyogan.

Hari pertama diisi dengan kegiatan penggalian potensi kelompok usaha bersama yang terdapat di Desa Nyogan. Sebelum acara dimulai didahului dengan kegiatan registrasi dan pembagian KIT yang terdiri atas tas, block note, pena dan tanda peserta. Kemudian dilanjutkan dengan acara pembukaan yang dihadiri oleh Kepala Desa Nyogan , Ketua dan anggota Tim Pengabdian. Setelah acara pembukaan yang ditutup dengan pembacaan doa, maka dilanjutkan dengan pematerian. Dalam kegiatan ini masing-masing para peserta memaparkan kegiatan kelompok usaha bersamanya, termasuk di dalamnya mengenai permasalahan yang ada di masing-masing kelompok. Aktivitas yang ada di masing-masing sangat beragam dan dapat dikelompokkan menjadi aktif, sedang dan kurang aktif dan bahkan cenderung tidak jalan. Setelah melakukan maping usaha dan inventarisasi permasalahan yang ada, maka pada hari kedua dilakukan penyampaian materi Manajemen kelompok usaha untuk menjadi KUBE yang berhasil dan berkelanjutan. Indikator keberhasilan usaha menurut Dwi Riyanti (2003:28), Benedicta Prihatin Dwi, Riyanti. (2003). Menyatakan bahwa kriteria yang cukup signifikan untuk menentukan keberhasilan suatu usaha dapat dilihat dari :

1. Peningkatan dalam akumulasi modal atau peningkatan modal

2. Jumlah produksi

3. Jumlah pelanggan

4. Perluasan usaha

5. Perluasan daerah pemsaran

6. Perbaikan sarana fisik dan

7. Pendapatan usaha

Pelaksanaan kegiatan ini dilakukan dengan metode ceramah dengan bantuan slide untuk menyampaikan materi dan menampilkan foto serta menayangkan film. Di sela-sela kegiatan ceramah juga dilakukan diskusi untuk mengakomodir pertanyaan dan pengalaman dari peserta. Selama pelaksanaan kegiatan ini peserta nampak antusias dan bersemangat serta mengikuti semua materi sampai berakhir.

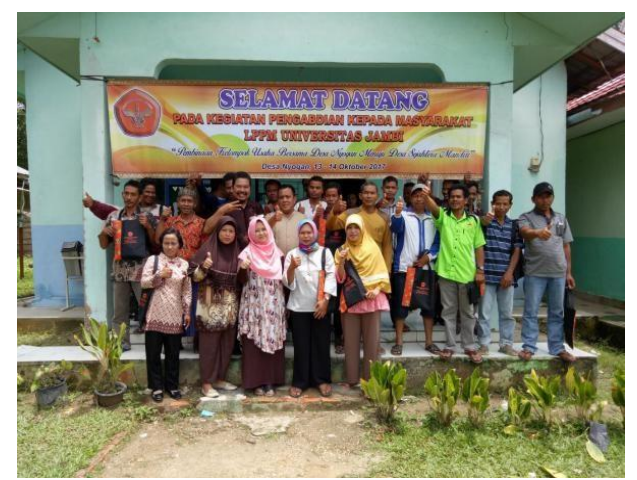

Gambar 3. Foto Bersama Peserta

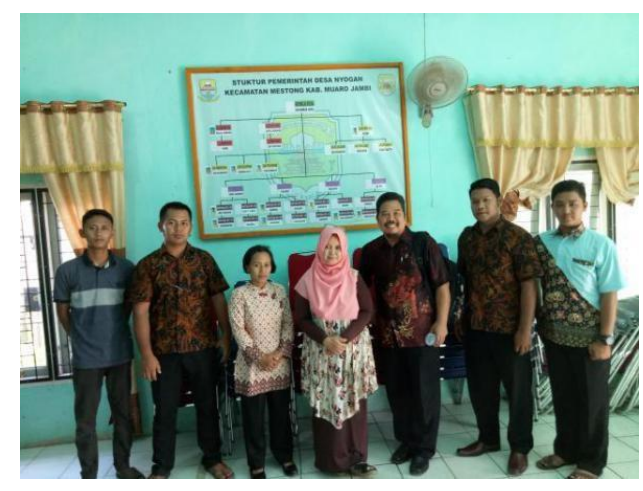

Gambar 4. Tim dan Aparat Desa 
Kegiatan Tahap II dilakukan dengan menghadirkan pelaku usaha yang telah mapan dan dalam menapaki usahanya mengalami jatuh bangun. Pelaku usaha yang dipilih adalah pelaku usaha dengan jenis usaha yang mendekati usaha dari kelompok usaha bersama Desa Nyogan. Materi yang disampaikan adalah Kiat Sukses dalam pengembangan dan kemajuan usaha. Dalam materi ini disampaikan bahwa pada saat menjalankan suatu usaha tidak selalu dapat langsung menjadi sukses dan adakalanya ditemui hambatan hambatan yang dapat menggoyang kekuatan pemilik usaha. Untuk itu diperlukan kepemilikan pribadi yang tangguh dari seorang pelaku usaha, sehingga tidak mudah putus asa. Hal ini sesuai dengan pendapat Cartwright, Roger. (2003) bahwa seorang entrepreneur harus memiliki semangat untuk maju, pantang menyerah dan selalu berpikiran positif. Permasalahan yang terjadi pada usaha yang sedang ditekuni harus diupayakan jalan keluarnya secepat mungkin. Setiap permasalahan yang timbul harus secepatnya diatasi. Jangan pernah berfikir untuk menimbun permasalahan dan baru berpikir untuk mengatasinya secara serentak. Para peserta sangat bersemangat dalam diskusi, banyak hal yang ditanyakan, terutama hal hal yang berkaitan dengan permasalahan permasalahan yang muncul dalam berwirausaha dan upaya untuk mengatasinya. Melihat peserta yang begitu bersemangat, pemateripun makin bersemangat menceritakan pengalamannya, yaitu suka duka yang dihadapi sebagai pengusaha yang memiliki hanya satu jenis usaha. Pada saat ini telah dilakukan pembukaan cabang usaha di beberapa tempat.

Kolaborasi kelompok usaha untuk menangkap permintaan pasar merupakan materi kegiatan pada hari ke dua pada tahap II. Pada materi ini dijelaskan bahwa dalam menjalankan usaha tidak harus hanya mengandalkan jenis kegiatan yang dimiliki saja. KUBE di Desa Nyogan berjumlah 24 kelompok dengan jenis usaha sebanyak 12 macam. Masing-masing KUBE hanya memiliki satu jenis kegiatan saja, misalnya sewa tenda, sewa kursi, sewa pelaminan, sewa piring. Pada umumnya pihak keluarga pengantin tidak mau repot dalam menyelenggarakan hajatnya, sehingga mereka lebih memilih sistem paket, dimana semua kebutuhan acara hanya ditangani oleh satu orang saja. Keinginan konsumen seperti ini dapat ditangkap dengan cara berkolaborasinya beberapa kelompok usaha bersama, dengan demikian konsumen akan merasa terbantu dan kelompok usaha bersama juga akan semakin maju.

Kegiatan UMKM memiliki peran yang sangat penting dalam memajukan perekonomian karena sektor ini telah teruji memiliki daya tahan terhadap krisis ekonomi. UMKM menyediakan lapangan kerja yang luas yang mampu meningkatkan kesejahteraan masyarakat. Selain itu, perkembangan UMKM di pedesaan akan mengurangi kesenjangan pemerataan pembangunan antara pedesaan dengan perkotaan (Rhenald, Kasali, 2012).

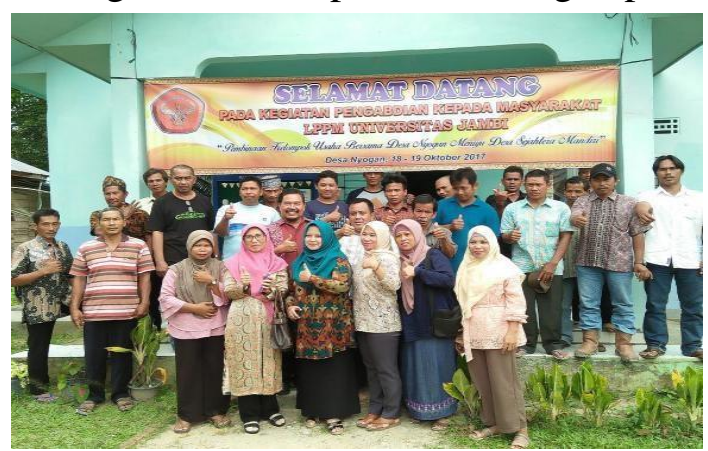

Gambar 5. Usai Kegiatan Tahap II

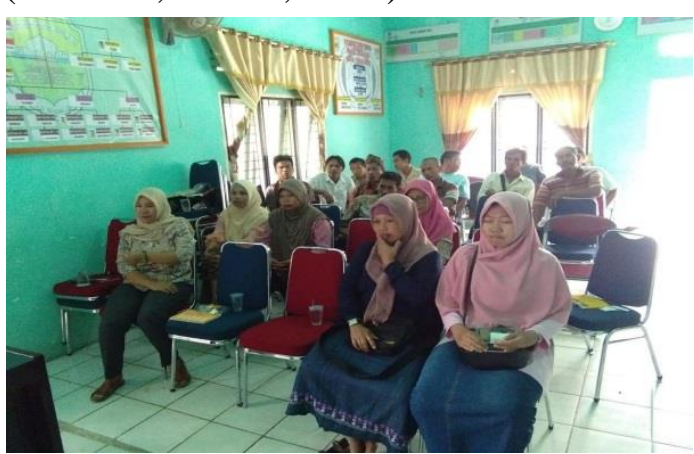

Gambar 6. Keseriusan Peserta 
Pelaksanaan kegiatan tahap III dilakukan di luar Desa Nyogan. Kegiatan ini bertujuan untuk membuka wawasan dari para peserta mengenai kegiatan berwirausaha melalui penggalian pengalaman dari wirausahawan yang memulai kegiatannya dengan modal yang sangat minim. Namun karena kemampuannya dalam menggali potensi daerah yang ditempatinya untuk dapat dijadikan mesin penghasil pundi pundi rupiah akhirnya daerah tersebut menjadi ramai dikunjungi oleh wisatawan domestik dan mancanegara.

Rencana untuk berkunjung disepakati dengan perjanjian peserta dan tim bertemu di Jembatan Batang Hari II pada pukul 8.30 WIB. Peserta datang dengan menggunakan transportasi Bis Damri yang pembiayaannya ditanggung oleh tim pengabdian. Anggota kegiatan ini tidak hanya peserta, melainkan juga ada peserta yang membawa keluarganya. Mereka datang tidak hanya untuk belajar melainkan juga dijadikan ajang untuk rekreasi. Setelah berkumpul di tempat yang telah dijanjikan, maka selanjutnya melakukan perjalanan ke lokasi Umo Teluk, dan sampai di lokasi sekitar pukul 9.30 WIB.

Sesampai di lokasi dilakukan pembayaran tiket masuk lokasi yang semuanya ditanggung oleh Tim Pengabdian dengan harga Rp. 5.000,- per orang, selanjutnya langsung diterima oleh pimpinan pengelola lokasi dan dilakukan acara diskusi. Dalam sambutan yang disampaikan oleh pimpinan pengelola, bahwa kegiatan usaha ini diawali dengan memiliki modal hanya Rp. 3.000.000,-. Dengan pemikiran bahwa Jambi sangat minim objek wisata, maka objek wisata candi akan sangat menarik untuk dikunjungi, dan sepanjang perjalanan menuju candi tidak ditemukan objek wisata yang menarik dikunjungi. Maka difikirkanlah upaya apa yang dapat dilakukan untuk memancing perhatian wisatawan yang akan ke candi untuk dapatt mampir ke lokasi serta meninggalkankan pundi pundi rupiahnya. Akhirnya dipilihlah suatu lokasi di tepi jalan besar yang merupakan areal persawahan. Pertanaman padi yang ada di dalam lokasi tetap dipertahankan. Dalam upaya menjadikan lokasi sebagai objek wisata, maka dilakukanlah penataan lokasi. Penataan yang dimaksud misalnya berusaha mendandani semenarik mungkin orang orangan yang ada di sawah yang berperan dalam menghalau burung. Kemudian dibuatlah tempat tempat istirahat dari bahan kayu dengan kreasi yang unik. Rumah pohon, ayunan dan masih banyak hal-hal yang menarik didiskusikan. Dan yang tidak kalah menariknya adalah di lokasi ini juga tersedia kantin kecil yang menjual berbagai jenis produk, mulai dari makanan, jajanan ringan dan Souvenir. Adanya perubahan ini menarik wisatawan yang akan mengunjungi candi untuk mampir dan menikmati karya inovasi masyarakat di Umo teluk. Hampir setiap hari ada pengunjung yang datang dan bahkan pada hari hari tertentu pengunjung yang datang dapat mencapai 1300 orang. Dalam konsep pembangunan berkelanjutan, pembangunan dilaksanakan tidak hanya terfokus pada kegiatan ekonomi, melainkan juga memperhatikan persoalan lingkungan dan sosial.

Sociopreneur atau wirausaha sosial cenderung melihat masalah sebagai peluang untuk membentuk sebuah model bisnis baru yang bermanfaat bagi pemberdayaan masyarakat sekitar. Hasil yang ingin dicapai bukan keuntungan materi atau kepuasan pelanggan, melainkan bagaimana gagasan yang diajukan dapat memberikan dampak baik bagi masyarakat (Adie, Nugroho, dkk, 2013).

Penguatan Usaha Keswadayaan masyarakat dilakukan untuk menjawab persoalan krusial "employment-income-growth" di desa. Penguatan ini bertumpu pada penumbuhan ekonomi 
kerakyatan di lingkungan desa dengan melibatkan rumah tangga, kelompok usaha bersama dan lembaga pembiayaan yang mampu mendongkrak modal dan investasi bagi kelanjutan usaha individu dan atau kelompok. Desa produktif sebagai pusat pertumbuhan dikembangkan sektor hulu yang menjalankan ekonomi kreatif. Sektor hulu meliputi pertanian, perikanan, peternakan, perkebunan atau industri rumah tangga lainnya sesuai kebutuhan desa. Sektor hulu dikembangkan dalam bentuk usaha ekonomi kreatif dengan mengandalkan potensi dan sumber yang dimiliki oleh masyarakat berdasarkan kearifan lokal, sehingga "one village one product" dapat diwujudkan di desa. Usaha tersebut dilakukan secara serentak melalui Ekonomi kelompok yaitu Kelompok Usaha Bersama (KUBE). Muhi (2012) menyatakan bahwa secara umum pembangunan desa meliputi dua aspek yang sangat penting, yakni 1) Aspek fisik, yaitu pembangunan yang obyek utamanya dalam aspek fisik; 2) Aspek pemberdayaan insani, yaitu pembangunan yang obyek utamanya aspek pengembangan dan peningkatan kemampuan, skill, dan memberdayakan masyarakat di daerah pedesaan sebagai warganegara. Tujuan utamanya adalah untuk membantu masyarakat yang masih tergolong marginal agar dapat melepaskan diri dari belenggu keterbelakangan sosial ,ekonomi, politik dan lain sebagainya"

\section{KESIMPULAN}

Dari hasil kegiatan Pengabdian kepada masyarakat yang telah dilakukan, maka dapat diambil kesimpulan :

1. Peserta merasakan manfaat yang besar dari pelaksanaan kegiatan pengabdian ini KUBE yang putus asa dan akan nnmenutup usahanya mulai terlihat bersemangat dan berencana untuk mengaktifkan kembali usaha kelompok bersamanya.

2. Peserta KUBE berkolaborasi antar kelompok usaha bersama untuk menerima pesanan paket dari konsumen.

3. Peserta mulai memahami bahwa dalam melakukan usaha tidak selalu langsung menjadi sukses melainkan dapat mengalami hambatan yang berasal dari dalam kelompok maupun luar kelompok.

4. Adanya keinginan bersama antara masyarakat dan aparat desa untuk menggali potensi desa untuk dijadikan desa wisata yang dapat menarik wisatawan sehingga dapat membantu meningkatkan kesejahteraan masyarakat.

\section{SARAN}

1. Kegiatan pendampingan terhadap masyarakat desa hendaknya terus dilakukan hingga tercapainya Desa Sejahtera Mandiri.

2. Perlu adanya kerjasama yang baik antara masyarakat, Pemerintah dan Akademisi untuk mempercepat tercapainya Desa Sejahtera Mandiri.

\section{UCAPAN TERIMAKASIH}

Dalam kesempatan ini, Perkenankanlah kami menghaturkan ucapan terimakasih kepada berbagai pihak yang telah membantu terlaksananya kegiatan pengabdian kepada masyarakat ini, sebagai berikut : Rektor Universitas Jambi, Ketua LPPM Universitas Jambi, Kepala Desa 
Nyogan Kecamatan Mestong, Kepala Pusat Studi di lingkungan Universitas Jambi, Para mahasiswa yang terlibat dalam kegiatan pengabdian ini, dan berbagai pihak yang dalam hal ini tidak dapat disebutkan satu persatu.

Semoga segala sesuatu yang dilakukan dalam kegiatan pengabdian ini, dapat dicatat sebagai amal ibadah di hadapan Allah SWT.

\section{DAFTAR PUSTAKA}

Adie, Nugroho, dkk, 2013, Menumbuh kembangkan Socioecopreneur Melalui Kerjasama Strategis, Penerbit Penebar Swadaya, Jakarta.

Benedicta Prihatin Dwi, Riyanti. (2003). Kewirausahaan Dari Sudut Pandang. Psikologi Kepribadian. Jakarta : Grasindo.

Cartwright, Roger. 2003. Pribadi Entrepreneur. Prestasi Pustaka, Jakarta.

Muhi, A.H., 2012. Fenomena Pembangunan Desa. Institut Pemerintahan Dalam Negeri, Jatinangor.

Rhenald, Kasali, 2012, Cracking Entrepreneurs, Inilah Para Crackers Lokal Yang Tak Ada Matinya, Gramedia Pustaka Utama, Jakarta.

Undang Undang No. 20 Tahun 2008.

Undang Undang No.11 Tahun 2009 tentang Kesejahteraan Sosial.

Undang Undang No.13 Tahun 2011 tentang Penanganan Fakir Miskin.

Wasistiono, S., 2003. Kapita Selekta Manajemen Pemerintahan Daerah. Fokus media, Bandung. 